\title{
Keanekaragaman Laba-laba Pada Pertanaman Jambu Mete Monokultur dan Polikultur di Lombok Utara
}

\author{
Diversity of Spiders on Monoculture and Polyculture Cashew Plantation in Lombok Utara
}

I Wayan Suana ${ }^{*}$ dan Hery Haryanto

${ }^{1}$ Program Studi Biologi, Fakultas MIPA, Universitas Mataram, Jl. Majapahit 62 Mataram 83125

${ }^{2}$ Program Studi Agroteknologi, Fakultas Pertanian, Universitas Mataram, Jl. Pendidikan 37 Mataram 83125

E-mail: swansurya@yahoo.com.*Penulis untuk korespondensi

\begin{abstract}
Agricultural practice is suspected to influence the availability of spiders in cashew plantation. The aim of this research was to study the diversity of spider in two different agricultural practices: monoculture and polyculture. The research was conducted in cashew plantations in Desa Kayangan (monoculture) and Desa Salut (polyculture), Lombok Utara. Two trapping techniques were used to sample the spiders: sweep net and pitfall trap. In each study area, 10 sampling sites were selected along line transect that was 5000 meters long. The study found 36 species of spiders from 12 families. The diversity and richness of spiders were higher in the polyculture cashew plantation than that in monoculture. Habitat structure was more complex in the polyculture cashew plantation; hence many species of spiders were able to coexist there.
\end{abstract}

Key words: Cashew plantation, monoculture, polyculture, spider

\begin{abstract}
Abstrak
Cara bercocok tanam diduga mempengaruhi kehadiran laba-laba pada pertanaman jambu mete. Penelitian ini bertujuan mempelajari keanekaragaman laba-laba pada dua cara bercocok tanam: monokultur dan polikultur. Penelitian dilakukan pada pertanaman jambu mete di Desa Kayangan (monokultur) dan Desa Salut (polikultur), Lombok Utara. Pengambilan sampel labalaba menggunakan dua perangkap yaitu: jaring ayun dan perangkap sumuran. Pada setiap lokasi penelitian ditentukan 10 titik pengambilan sampel yang terletak pada garis transek sepanjang 5000 meter. Hasil penelitian mendapatkan 36 jenis laba-laba dari 12 suku. Keanekaragaman dan kekayaan jenis laba-laba lebih tinggi di pertanaman jambu mete yang bersifat polikultur dibandingkan dengan monokultur. Struktur habitat lebih kompleks di pertanaman jambu mete yang bersifat polikultur, sehingga lebih banyak jenis laba-laba dapat berkoeksistensi di sana.
\end{abstract}

Kata kunci: Pertanaman jambu mete, monokultur, polikultur, laba-laba

Diterima: 08 Februari 2010, disetujui: 06 Mei 2010

\section{Pendahuluan}

Kabupaten Lombok Utara merupakan salah satu pusat pengembangan jambu mete di Nusa Tenggara Barat (NTB). Dari 56.000 ha pertanaman jambu mete di NTB, 21.436 ha terdapat di Lombok Utara (Anonim, 2009). Dalam upaya pengembangan jambu mete di NTB, dijumpai beberapa kendala seperti serangan hama dan penyakit. Serangan serangga hama telah dilaporkan menyebabkan penurunan produksi buah sebesar $17,8 \%$ sampai $28,2 \%$ (Anonim, 2003). Upaya pengendalian serangga hama yang dilakukan petani selama ini adalah dengan menggunakan pestisida (Laudensius et al., 2003). Upaya tersebut tidak membuahkan hasil nyata karena gejala serangan terus menunjukkan peningkatan dari tahun ke tahun. Pada tahun 2000, di Lombok Utara tercatat 1.150 ha tanaman diserang, dan pada tahun 2002 meningkat tiga kali lipat menjadi 3.432 ha (Anonim, 2003). Sampai akhir tahun 2008 luas serangan mencapai $6.430,8$ ha atau sekitar $30 \%$ dari luas areal pertanaman jambu mete di Lombok Utara (Anonim, 2009). Oleh sebab itu, 
harus dicari upaya pengendalian hama alternatif yang efektif dan aman bagi lingkungan.

Pengendalian hama menggunakan musuh alami merupakan suatu alternatif strategi pengendalian hama yang saat ini dikembangkan untuk menggantikan pestisida. Penggunaan pestisida cenderung merusak lingkungan, membahayakan kesehatan masyarakat, dan bahkan dapat menurunkan kualitas hasil pertanian akibat residu pestisida sehingga sulit bersaing dalam pasar internasional (Laudensius et al., 2003).

Laba-laba perlu dipertimbangkan sebagai salah satu musuh alami hama tanaman jambu mete. Semua laba-laba hidup sebagai pemangsa, terutama memangsa serangga, sehingga berperan dalam mengontrol populasi serangga (Foelix, 1996). Laba-laba mampu menekan populasi serangga lebih besar daripada burung maupun pemangsa serangga lainnya (Tarabaev dan Sheykin, 1990). Laba-laba juga bersifat polifag sehingga sangat potensial sebagai musuh alami untuk berbagai jenis serangga hama (Riechert dan Lokley, 1984). Selain itu, laba-laba juga mampu menempati berbagai macam habitat, sehingga memiliki penyebaran yang luas (Levi dan Levi, 1990; Marc et al., 1999).

Perbedaan cara bercocok tanam diduga berpengaruh terhadap keanekaragaman laba-laba pada ekosistem pertanian. Cara bercocok tanam yang bersifat polikultur akan menyediakan lebih beragam habitat dibandingkan dengan cara bercocok tanam yang bersifat monokultur, sehingga diduga ada perbedaan keanekaragaman laba-laba pada kedua ekosistem pertanian tersebut. Penelitian ini bertujuan mempelajari keanekaragaman laba-laba pada pertanaman jambu mete monokultur dan polikultur di Lombok Utara. Hasilnya diharapkan dapat memberikan rekomendasi cara bercocok tanam yang ideal untuk memelihara keanekaragaman laba-laba, sehingga peranannya sebagai musuh alami hama dapat ditingkatkan.

\section{Metode Penelitian}

\section{Lokasi dan Waktu Penelitian}

Penelitian dilaksanakan pada pertanaman jambu mete di Desa Kayangan dan Desa Salut, Lombok Utara, serta di Laboratorium Biologi
Dasar, FMIPA, Universitas Mataram (Unram). Pertanaman jambu mete di Desa Kayangan bersifat monokultur. Sebaliknya, pertanaman jambu mete di Desa Salut bersifat polikultur. Di sela-sela pertanaman jambu mete, petani menanam tanaman semusim, seperti: jagung, kacang hijau dan kedalai. Pertanaman jambu mete di Desa Salut, berbatasan dengan hutan Taman Nasional Gunung Rinjani, sehingga banyak terdapat vegetasi liar.

Pengambilan sampel di lapang berlangsung selama tiga bulan (Maret sampai Mei 2008). Identifikasi laba-laba di laboratorium dilaksanakan selama enam bulan (Maret sampai Agustus 2008).

\section{Pelaksanaan Penelitian}

Pada pertanaman jambu mete di Desa Kayangan dan Desa Salut masing-masing dibuat garis transek sepanjang 5.000 meter. Pada setiap jarak 500 meter dibuat titik pengambilan sampel, sehingga didapatkan 10 titik sampel. Bila pada titik sampel tidak terdapat tanaman jambu mete, diambil tanaman jambu mete terdekat sebagai titik sampel. Pada tiap-tiap tanaman jambu mete yang terpilih sebagai sampel kemudian dilakukan pengambilan sampel laba-laba memakai jaring ayun dan perangkap sumuran. (Levi dan Levi, 1990; Marc et al., 1999). Jaring ayun dipakai untuk menangkap laba-laba yang hidup pada tajuk tanaman. Jaring ayun yang dipakai pada penelitian ini mempunyai ukuran diameter mulut jaring $30 \mathrm{~cm}$ dengan panjang tangkai 5 meter. Jaring ayun diayun-ayunkan pada tajuk tanaman sebanyak 20 kali. Laba-laba yang tertangkap dalam jaring ayun diambil menggunakan aspirator atau kuas halus.

Perangkap sumuran dipakai untuk menangkap laba-laba yang bergerak di permukaan tanah. Perangkap sumuran terbuat dari gelas plastik bekas air mineral dengan diameter mulut gelas $8 \mathrm{~cm}$ dengan tinggi $10 \mathrm{~cm}$. Gelas diisi dengan larutan air sabun, kemudian ditanam di tanah hingga mulut gelas rata dengan permukaan tanah. Sebanyak tiga buah perangkap dipasang pada setiap titik pengambilan sampel, dan dipertahankan tetap terpasang selama 1 x 24 jam.

Sampel laba-laba yang terkumpul lalu disimpan dalam botol koleksi berlabel dan diawetkan dengan alkohol $70 \%$ untuk kemudian 
diidentifikasi di Laboratorium Biologi Dasar, FMIPA, Unram. Sampel laba-laba yang berukuran kecil diidentifikasi dengan bantuan mikroskop binokuler, sedangkan yang berukuran cukup besar diamati dengan kaca pembesar. Penentuan jenis laba-laba berdasarkan karakter morfologi (morfospesies). Karakter-karakter morfologi tersebut, antara lain: jumlah dan pola susunan mata, rambut-rambut kaku pada tungkai, jumlah dan bentuk spineret, dan pola warna tubuh. Hasil pengamatan kemudian dicocokkan dengan beberapa buku identifikasi, antara lain: Spider of Japan in Color (Yaginuma, 1986), Spider and Their Kin (Levi dan Levi, 1990), Forest Spiders of South East Asia (Deeleman-Reinhold, 2001), Spider Families of the Word (Jocque dan Dippenaar-Schoeman, 2006). Sampel laba-laba yang telah diidentifikasi disimpan kembali dalam botol koleksi yang diberi pengawet alkohol 70\% dan diberi label.

\section{Analisis Data}

Penentuan keanekaragaman jenis laba-laba didasarkan pada indeks keanekaragaman Shannon dan Wiener $\left(\mathrm{H}^{\prime}\right)$ (Krebs, 1999) dengan rumus:

$$
\begin{aligned}
& \mathrm{H}^{\prime}=-\underset{\mathrm{i}=1}{\mathrm{~s}} \mathrm{P}_{\mathrm{i}}\left(\log _{\mathrm{e}} \mathrm{P}_{\mathrm{i}}\right) \\
& \mathrm{H}^{\prime}=\text { indeks keanekaragaman Shannon dan Wiener } \\
& \mathrm{P}_{\mathrm{i}}=\text { proporsi jenis ke-i terhadap total jumlah jenis }
\end{aligned}
$$

\section{Hasil dan Pembahasan}

\section{Keanekaragaman Laba-laba pada Pertanaman Jambu Mete}

Sebanyak 36 jenis laba-laba dari 12 suku telah dikoleksi dengan jaring ayun dan perangkap sumuran pada pertanaman jambu mete di Desa Kayangan dan Desa Salut, Lombok Utara (Tabel 1).

Suku Araneidae terdiri delapan jenis, yaitu Argiope sp, Cyclosa sp, Cyrtophora sp, Eriovixia sp, Gasteracantha sp, Neoscona sp, Nephila sp, dan Parawixia sp. Neoscona sp merupakan jenis yang paling dominan di antara ke delapan jenis laba-laba tersebut. Mereka tersebar luas pada kedua ekosistem pertanaman jambu mete. Suku Araneidae merupakan labalaba pembuat jaring bulat. Jaringnya dibuat diantara percabangan dan daun jambu mete.

Clubionidae adalah suku laba-laba yang tidak membuat jaring untuk menjebak mangsanya. Mereka mendapatkan mangsanya dengan cara berburu diantara daun-daun jambu mete serta pada batang tanaman. Clubionidae terdiri atas tiga jenis, yaitu: Agroeca sp, Cheiracanthium sp, dan Clubiona sp. Cheiracanthium dan Clubiona merupakan jenis yang sangat dominan dibandingkan dengan semua jenis yang ditemukan dalam penelitian ini. Clubiona sangat melimpah ditemukan pada kedua ekosistem.

Tabel 1. Keanekaragaman laba-laba pada pertanaman jambu mete di Desa Kayangan dan Desa Salut, Lombok Utara (Maret-Mei 2008).

\begin{tabular}{clccc}
\hline \hline No. Suku & Total Jenis & \multicolumn{2}{c}{ Lokasi } \\
\cline { 3 - 5 } & & 8 & Desa Kayangan & Desa Salut \\
\hline \hline 1. & Araneidae & 3 & 4 & 7 \\
2. & Clubionidae & 1 & 1 & 2 \\
3. & Hersiliidae & 5 & 2 & 5 \\
4. & Lycosidae & 1 & 1 & 1 \\
5. & Metidae & 1 & 1 & 1 \\
6. & Oxyopidae & 1 & - & 1 \\
7. & Pholcidae & 7 & 7 & 1 \\
8. & Salticidae & 1 & 1 & 1 \\
9. & Scytodidae & 1 & 1 & 6 \\
10. & Tetragnathidae & 6 & 4 & 1 \\
11. & Theridiidae & 1 & - & $\mathbf{3 2}$ \\
12. & Thomisidae & $\mathbf{3 6}$ & $\mathbf{2 5}$ & \\
\hline \hline
\end{tabular}


Salticidae juga merupakan suku laba-laba yang tidak membuat jaring untuk menangkap mangsanya. Mereka mendapatkan mangsa dengan cara berburu diantara daun-daun, bunga serta batang tanaman. Cosmophasis ditemukan lebih sering berburu di dedaunan dan bunga, sedangkan Plexippus berburu pada rantingranting dan dedaunan. Kadang-kadang Plexippus juga ditemukan pada batang tanaman. Anggota suku Salticidae yang lain yang ditemukan dalam penelitian ini adalah: Bionar sp, Hasarius sp, Hyllus sp, Phaecius sp, dan Simaetha sp. Kelima jenis ini kurang dominan dibandingkan dengan Cosmophasis dan Plexippus.

Hersiliidae, Metidae, Oxyopidae, Pholcidae, Scytodidae, Tetragnathidae, Theridiidae dan Thomisidae merupakan suku laba-laba yang tidak dominan serta penyebarannya tidak merata pada kedua ekosistem tersebut. Thomisidae dan Pholcidae hanya ditemukan pada pertanaman jambu mete di Desa Salut. Lycosidae merupakan laba-laba pemburu di tanah atau serasah. Mereka ditemukan pada ekosistem pertanaman jambu mete di Desa Salut yang terdapat banyak serasah di permukaan tanah.

Kompleksitas struktur habitat mempunyai peranan yang besar dalam mempengaruhi keanekaragaman laba-laba pada suatu habitat. Rosenzweig (1995), Marc et al., (1999), Topping (1999) serta Suana dan Haryanto (2007) menyatakan bahwa keanekaragaman jenis umumnya meningkat sejalan dengan meningkatnya keragaman struktur habitat. Tabel 2 menunjukkan ada perbedaan keanekaragaman dan kekayaan jenis laba-laba yang terdapat pada ekosistem pertanaman jambu mete di Desa Kayangan dan Desa Salut.

Perbedaan arsitektur pohon yang menyusun suatu ekosistem mempengaruhi keanekaragaman dan kekayaan jenis laba-laba (Raizer dan Amaral, 2001). Tanaman jambu mete yang terdapat di Desa Salut memiliki habitus lebih tinggi dengan rata-rata tinggi pohon 5 meter, sedangkan yang terdapat di Desa Kayangan tinggi pohonnya rata-rata 2 meter. Selain mempunyai habitus lebih tinggi, tanaman jambu mete di Desa Salut juga memiliki diameter tutupan tajuk yang lebih lebar dengan rata-rata 4 meter, dibandingkan dengan tanaman jambu mete di Desa Kayangan yang rata-rata lebarnya hanya 2 meter. Perbedaan arsitektur pohon ini menyebabkan ketersediaan relung yang berbeda pada kedua ekosistem tersebut, yang pada akhirnya akan mempengaruhi keberadaan laba-laba pada ekosistem tersebut. Laba-laba pembuat jaring, misalnya, membutuhkan ruang yang cukup untuk membangun jaring perangkapnya (Rypstra, 1983). Tajuk tanaman yang terlalu rapat menyebabkan laba-laba pembuat jaring tidak leluasa untuk membangun jaringnya. Fenomena ini menunjukkan bahwa struktur fisik habitat mempunyai peranan penting dalam pemilihan habitat oleh laba-laba, khususnya bagi laba-laba pembuat jaring. Hal yang sama juga ditemukan oleh Janetos (1986), Riechert dan Gillespie (1986), Uetz (1991) serta Hurd dan Fagon (1992) bahwa struktur fisik habitat menjadi pertimbangan pertama bagi laba-laba pembuat jaring untuk menginvasi suatu habitat di samping faktor lain seperti ketersediaan mangsa.

Keberadaan tanaman semusim, seperti: jagung, kacang hijau dan kedelai di sela-sela pertanaman jambu mete di Desa Salut menciptakan ekosistem yang lebih kompleks dibandingkan dengan di Desa Kayangan. Ekosistem yang kompleks menyediakan beragam tipe habitat sehingga semakin banyak jenis laba-laba yang dapat berkoeksistensi di dalamnya. Adanya habitat pinggir (edge habitat), yaitu hutan Taman Nasional Gunung Rinjani yang berbatasan dengan pertanaman jambu mete di Desa Salut, semakin menambah kompleksitas habitat. Vegetasi liar yang tumbuh di hutan tersebut merupakan salah satu faktor yang berpengaruh terhadap keberadaan laba-laba pada ekosistem pertanaman jambu mete di Desa Salut. Hal yang sama juga ditemukan oleh Shelton dan Edwards (1983), yang menyatakan bahwa beberapa serangga pemangsa ditemukan sangat melimpah pada pertanaman kedelai yang terdapat vegetasi liar di sekitarnya.

Vegetasi liar menyediakan reservoar bagi pemangsa-pemangsa tersebut berupa mangsa alternatif serta iklim mikro yang lebih sesuai (Rodenhouse et al., 1992). Opdam (2002) menyatakan bahwa jenis-jenis yang dapat beralih (shifting species) dapat menggunakan vegetasi liar di sekitar tanaman budidaya sebagai habitat sementara apabila tanaman budidaya mengalami gangguan, lalu melakukan rekolonisasi apabila 
habitat utamanya telah pulih kembali. Dengan demikian, hutan yang terdapat di dekat pertanaman jambu mete di Desa Salut dapat menjadi habitat pengungsian sementara bagi laba-laba, apabila pada pertanaman jambu mete terjadi gangguan. Saat panen berpotensi menimbulkan gangguan bagi laba-laba sehingga laba-laba harus mengungsi untuk sementara. Penyemprotan dengan pestisida yang secara berkala dilakukan oleh petani juga merupakan gangguan yang cukup serius bagi laba-laba dan komponen ekosistem lainnya. Hal ini mengindikasikan bahwa keberadaan vegetasi liar di sekitar pertanaman jambu mete dapat memberikan kontribusi yang besar dalam menjaga kestabilan ekosistem, khususnya bagi laba-laba yang merupakan salah satu musuh alami hama tanaman jambu mete yang sangat potensial.

Tabel 2. Indeks keanekaragaman $\left(\mathrm{H}^{\prime}\right)$ dan kekayaan $(\mathrm{S})$ jenis laba-laba pada pertanaman jambu mete di Desa Kayangan dan Desa Salut, Lombok Utara (Maret-Mei 2008).

\begin{tabular}{lcc}
\hline \hline \multirow{2}{*}{ Indeks } & \multicolumn{2}{c}{ Lokasi } \\
\cline { 2 - 3 } & Desa Kayangan & Desa Salut \\
\hline \hline Keanekaragaman $\left(\mathrm{H}^{\prime}\right)$ & 3,4 & 3,5 \\
Kekayaan $(\mathrm{S})$ & 25 & 32 \\
\hline \hline
\end{tabular}

\section{Simpulan dan Saran}

\section{Simpulan}

Keanekaragaman jenis laba-laba lebih tinggi pada pertanaman jambu mete di Desa Salut yang bersifat polikultur dibandingkan dengan Desa Kayangan yang bersifat monokultur. Perbedaan arsitektur pohon, keberadaan tanaman semusim, dan vegetasi liar yang terdapat di sekitar pertanaman jambu mete menyediakan beragam habitat, dan banyak jenis laba-laba yang dapat berkoeksistensi di dalamnya. Vegetasi liar dapat menjadi reservoar bagi laba-laba.

\section{Saran}

Cara bercocok tanam yang bersifat polikultur sangat dianjurkan untuk diterapkan oleh petani jambu mete di Lombok Utara, sehingga keanekaragaman serta peranan labalaba sebagai musuh alami hama dapat ditingkatkan.

\section{Ucapan Terima Kasih}

Penulis mengucapkan penghargaan dan terima kasih kepada Direktorat Penelitian dan Pengabdian kepada Masyarakat (DP2M) Dirjen Dikti Depdiknas yang telah mensponsori penelitian ini, sesuai dengan Surat Perjanjian Pelaksanaan Hibah Penelitian Nomor:
028/SP2H/PP/DP2M/III/2008 tanggal 6 Maret 2008. Penghargaan juga penulis sampaikan kepada mahasiswa yang terlibat dalam penelitian ini: Heykal, Rizal dan Jumahir.

\section{Daftar Pustaka}

Anonim. 2003. Laporan Tahunan Dinas Perkebunan Nusa Tenggara Barat Tahun 2003. Dinas Perkebunan Nusa Tenggara Barat, Mataram.

Anonim. 2009. Laporan Tahunan Dinas Perkebunan Nusa Tenggara Barat Tahun 2009. Dinas Perkebunan Nusa Tenggara Barat, Mataram.

Deeleman-Reinhold, C.L. 2001. Forest Spiders of South East Asia. Brill, Leiden.

Foelix, R.F. 1996. Biology of Spider. Oxford University Press, New York.

Hurd, L.E. dan Fagon, W.F. 1992. Cursorial Spiders and Succession: Age or Habitat Structure? Oecologia, 92: 215-221.

Janetos, A.C. 1986. Web Site Selection: Are We Asking The Right Questions? In: Shear, W.A. (Eds.). Spiders: Webs, Behaviour, and Evolution: 9-22. Stanford University Press, California.

Jocquě, R. dan Dippenaar-Schoeman, A.S. 2006. Spider Families of the World. Royal Museum for Central Africa, Tervuren.

Krebs, C.J. 1999. Ecological Methodology. AddisonWesley, Menlo Park.

Laudensius, O., Yuda, P. dan Atmodjo, K. 2003. Analisis Insektisida Organoklorin pada Bulu Walet Sarang Putih (Collocalia fuciphaga Thunberg). Biota, VIII (2): 83-88. 
Levi, H.W. dan Levi, L.R. 1990. Spider and Their Kin. Golden Press, New York.

Marc, P., Canard, A. dan Ysnel, F. 1999. Spiders (Araneae) Useful for Pest Limitation and Bioindication. Agric. Ecosyst. Environ., 74: 229-273.

Opdam, P. 2002. Landeconet: The Study of Biodiversity in Changing Landscapes. http://www.nmw.ac.uk/ ITE/econet/opdam/html.25/05/2002.

Raizer, J. dan Amaral, M.E.C. 2001. Does the Structural Complexity of Aquatic Macrophytes Explain The Diversity of Associated Spider Assemblages? J. Arachnol, 29: 227-237.

Riechert, S.E. dan Lockley, T. 1984. Spiders as Biological Control Agents. Ann. Rev. Entomol., 29: 229320.

Riechert, S.E. dan Gillespie, R.G. 1986. Habitat Choice and Utilization in Web-building Spiders. In: Shear, W.A. (Eds). Spiders: Webs, Behaviour, and Evolution: 23-48. Stanford University Press, California.

Rodenhouse, N.L., Barrett, G.W., Zimmerman, D.M. dan Kemp, J.C. 1992. Effects of Uncultivated Corridors on Arthropod Abundances and Crop Yields in Soybean Agroecosystems. Agric. Ecosyst. Environ., 38:170-191.

Rosenzweig, M.L. 1995. Species Diversity in Space and Time. Camridge University Press, New York.
Rypstra, A.L. 1983. The Importance of Food and Space in Limiting Web-spider Densities: a Test using Field Enclosures. Oecologia, 59: 312-316.

Shelton, M.D. dan Edwards, C.R. 1983. Effects of Weeds on The Diversity and Abundance of Insects in Soybeans. Environ. Entomol., 12:196-298.

Suana, I.W. dan Haryanto, H. 2007. Keanekaragaman Laba-laba pada Ekosistem Sawah Monokultur dan Polikultur di Pulau Lombok. J. Biologi, XI (1): 1-5.

Tarabaev, C.K. dan Sheykin, A.A. 1990. Spiders as predator in apple-tree crowns in South-Eastern Kazakhstan. In: Koponen, S., Lehtinen, P.T. and Rinne, V. (Eds.). Acta Zool. Fenn., 190: 363-366.

Topping, C.J. 1999. An individual-based model for dispersive spiders in agroecosystems: simulations of the effects of landscape structure. J. Arachnol., 27: 378-386.

Uetz, G.W. 1991. Habitat Structure and Spider Foraging. In: Bell, S.S., McCoy, E.D. and Mushinsky, H.R. (Eds.). Habitat Structure: the Physical Arrangement of Objects in Space. Chapman \& Hall, London.

Yaginuma, T. 1986. Spider of Japan in Color. Hoikusha, Osaka. 